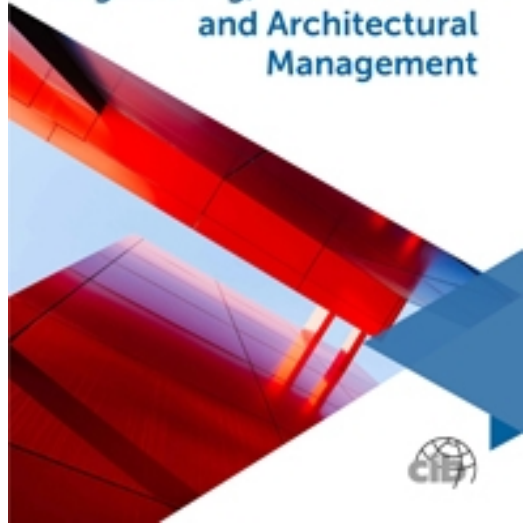

\title{
Critical Success Factors for Implementing Integrated Construction Project Delivery
}

\begin{tabular}{|r|l|}
\hline Journal: & Engineering, Construction and Architectural Management \\
\hline Manuscript ID & ECAM-02-2019-0073.R1 \\
\hline Manuscript Type: & Original Article \\
\hline Keywords: & $\begin{array}{l}\text { Construction Planning, Design Management, International Construction, } \\
\text { Management, Organization }\end{array}$ \\
\hline Abstract: & \\
\hline \multicolumn{2}{|c}{} \\
\hline
\end{tabular}

\section{SCHOLARONE' Manuscripts}



Construction Project Delivery

\section{Abstract}

5 Purpose - Identify the critical success factors (CSFs) to implement integrated project delivery 6 (IPD) systems in the Korean construction industry.

7 Design/methodology/approach - Categorized potential CSFs and analyzed them using factor 8 analysis and multiple regression analysis to choose the best ones based on responses from 9 Korean construction experts.

10 Findings - 29 potential factors were selected and categorized into seven CSFs using factor 11 analysis.

12 Originality/value - Useful as a reference for applying the IPD system in different developing countries and mid-sized construction industries.

Due to increasing project complexity, construction projects are carried out both separately and independently using various systems of delivery. For increasing large and complex construction projects to be carried out efficiently, a collaborative execution process needs to be devised to integrate and manage the vast amount of information and production activities. 19 For this to be successful in complex construction projects, an integrated project delivery (IPD) system has been applied, in which all project participants work together as a team from the outset. The aim of this study is to identify the critical success factors (CSFs) to implement IPD systems in the Korean construction industry. To this end, 29 potential factors were selected and categorized into seven CSFs using factor analysis. A multiple regression analysis shows that four of the seven CSFs have significant correlations with the research findings, four factors are essential among seven CSFs to implement IPD systems. They are 'Reform of contract law and adoption of appropriate IPD agreement form (CSF 1)', 'Team building and management for collaborative business process (CSF 2)', 'Early involvement and enhanced role of key participants (CSF 3)', and 'Improvement and utilization of BIM for collaborative process of 
29 IPD (CSF 4)'. Interestingly, some CSFs with typical features including "government leadership" and "IT technology support" can have a substantial impact on developing the construction sector and other construction-related industries. The outcomes of the study could be useful as a reference for applying the IPD system in Korea reflecting specific characteristic of the construction sector. These CSFs also could be applied in other different developing countries that have similar structures of the construction industry. In addition, identified CSFs also could be analyzed and applied in other mid-sized construction industries by the resetting of the analysis environment in accordance with their specific situation for implementing IPD.

Keywords collaborative working, construction management, construction team, project delivery.

\section{Paper type Research paper}

40

\section{Introduction}

Due to the trends of large scale and multifunctional project, the construction industry has suffered from various complications, such as cost overruns, schedule delays, quality issues, and limited trust between different project participants (O'Connor, 2009; Lahdenpera, 2012).

Almost all participants in construction projects have experienced sebacks caused by inadequate cooperation and poor administration throughout the project. These problems occur due to the competing interests of the project participants, incompatible individual habits, and a tack of substantial real-time information (CURT, 2004). These tendencies have resulted in the need for a new delivery system (Chan et al., 2004; Kent and Becerik-Gerber, 2010), and developing a collaborative project delivery system is currently one of the most significant issues in the construction industry (E1 Asmar et al., 2013). However, there are limitations in a conventional procurement system resulting from owners, contractors, architects, and other project participants making contracts separately. Thus, collaborative and integrated project implementation is difficult with a traditional procurement method due to a lack of project eontinuity and information sharing.

The American Institute of Architects (AIA) launched the integrated project delivery (IPD) 57 technique for construction projects to advance procurement systems using seamless integration and collaboration between project participants (AIA, 2007a). Based on contractual and 
59 behavioral principles, IPD emphasizes mutual respect and effective communication for the implementation of a project. Individual accomplishment in this new procurement system is subject to the sharing of information, knowledge, experiences, frameworks, business structures, and practices throughout the life of the project (Lahdenpera, 2012). Unlike traditional delivery systems, the main project participants are involved from the initial pre-design stage, including clients, architects, and contractors, who share their own distinct skills and knowledge to reduce project risk (Kent and Becerik-Gerber, 2010).

However, the IPD system is still not prominent in the global construction industry. Only a small number of case studies have been carried out in the United States (AIA, 2010b). There is limited explicit data on the effectiveness of IPD, it is challenging to encourage emerging construction industries to apply the IPD system in common practice. In addition, IPD is still in the test stage in developing construction sectors such as South Korea, and there is a lack of information on actual plans for applying IPD. Since the IPD was invented assuming the collaboration of the individual construction parts for a single project from early stage as a one team, it is highly likely that it will be successful in an overall fully matured and experienced built environment. For countries including South Korea that still do not have enough competency in soft skill such as contract management or risk management, there is careful research and practical feedback needed. However, there are still not many actual project cases even in a country in which IPD has been developed. Thus, determining the critical success factors (CSFs) is necessary to introduce IPD successfully. It is also necessary to determine the kinds of projects where it is more difficult or impossible to apply IPD.

The aim of this study is to identify the CSFs needed to implement an IPD in a developing construction industry. We categorized potential CSFs and analyzed them using factor analysis and multiple regression analysis to choose the best ones based on responses from Korean construction experts. This study was carried out based on the Korean construction environment for the application of IPD. However, our research findings may also be useful in other emerging construction industries or developing countries that do not yet have a fully mature market environment.

\section{LITERATURE REVIEW}




\subsection{Project delivery in general}

Project delivery comprises a series of contractual relationships that coordinate all the components of a project (Cho et al., 2010). Conventional project delivery systems (PDS) are based on a transactional contract, and examples include the fixed price lump sum, guaranteed maximum price, and cost-plus-fee systems. Halpin (2006) and El Asmar et al. (2013) consider a PDS to be an advancement or association of a framework that is needed to fulfill a project. They considered the establishment of a formal contract and casual connections between project partners to be important. According to Hanna (2010), a PDS is a framework that characterizes the relationship between different parties in an agreement, and it PDS plays a fundamental role in increasing mutual trust and clearly defining relationships between project participants based on a written agreement.

However, in recent years, other academic researchers and industrial experts have argued that there is limited cooperation and advancement when using a conventional PDS in actual construction projects (Middlebrooks, 2008; Swarup et al., 2011). Researchers have tried to develop procurement systems to complement PDS for complex and large-scale projects. Forbes and Ahmed (2011) suggest that PDS agreements only reward or punish the performance of individual team members who are bond by a contract without consideration of the effects on the entire team's performance.

According to the American Institute of Architects (AIA) (2010a), relational contracts are more valuable than transaction contract. They considered that transactional contracts are likely to lead to avoidance of responsibility and to conflict between contracting parties, whereas relational contracts help with cooperation, collaboration, and reliance among the principle project stakeholders. Common difficulties and potential conflicts in transactional contracts can be reduced by multi-party contracts (Thomsen, 2009). Integrated multi-party contracts have been used as a way of complementing PDS in ambiguous or complicated projects, which involve many different project participants and execution systems.

\subsection{Integrated project delivery}


117 Integrated project delivery (IPD) is one promising relational contract 1 system that provides 118 a platform for projects. Comparing to the traditional PDSs tightened by strict terms and 119 condition, since relational contract system is structured by the mutual trust rather than contract 120 clauses, it has fewer changes and a tighter schedule than traditional PDSs (AIA, 2007a). The 121 AIA defines IPD as an approach to project delivery that incorporates people, a framework, 122 business structures, and practices into one system. The greatest difference between IPD and 123 traditional PDSs (excluding integrated multi-party contracts) is the capacity to shift work 124 volume from the introductory periods of the design phase to the construction process, by which 125 all essential contributions are supported by different key stakeholders (Ilozor and Kelly, 2012). 126 From the initial project stage, main project players including owners, architects, and contractors 127 share their experience, technology, knowledge, and even foreseeable risks and benefits. With 128 integrated multi-party contracts between project team members, relationships can become 129 more reliable, cooperative, and respectful (AIA et al., 2010a; El Asmar et al., 2013).

130 According to the AIA (2007b), the benefits of IPD include collective backup capabilities 131 and problem-area identification by different project members, which increases the 132 effectiveness of project management. Various experts with different technical backgrounds 133 work together within one system, and even minor issues that do not seem critical initially but 134 have a serious impact later on can be managed in advance. This makes the problems to be 135 recognized and controlled in advance.

136 An absence of responsibilities, poor group collaboration, and unsatisfying interfaces are 137 some of the issues in a traditional procurement project (Volk et al., 2014). One approach to 138 these issues is to understand the overall procedure of project improvement. To ensure this, the 139 application of IPD supported by different project management tools is recommended, such as 140 a project management information system (PMIS) or building information modeling (BIM). 141 These management tools are useful for supplementing the issues of collaboration and 142 integration, and they are expected to realize the concept of IPD practically over the entire life 143 of the project. Monteiro et al. (2014) suggest that the goals of IPD can be fully achieved by 144 supporting other project management tools (such as BIM). IPD is recognized as a successful

\footnotetext{
${ }^{1}$ A relational contract is a contract whose effect is based upon a relationship of trust between the parties to which it pertains.
} 
145 delivery system that can be most effective when it is used with BIM. BIM can be used to 146 manage rich, object-oriented, intelligent, and parametric digital representation information for

147

148

149

150

151

152

153

154

155

156

157

158

159

160

161

162

163 164

165

166

167

168

169

170

171

172

173

174 construction projects.

To carry out a project successfully, there is a need for all project participants to cooperate as a team, including clients, design teams, quantity surveyors, contractors, and specialists. These individual experts can effectively pool their skills and experiences together in the IPD system, through which they share the benefits and risks of the project. Using different management tools, IPD can integrate different types of information, work processes, and activities into a single project boundary.

\section{METHODOLOGY}

The research process used in this study is shown in Figure 1. The research steps involve gathering data, maintaining data criteria, and determining the success factors of IPD. The limitations of the existing project delivery system and potential success factors for IPD were first determined, and then semi-structured interviews and questionnaire surveys were carried out to determinate the prerequisites for implementation of IPD that are used as dependent variables in multiple regression analysis and to ensure reliable data collection. Factor analysis and multiple regression analysis were then conducted to identify critical IPD factors that can be used in various developing construction industries.

\section{Insert $<$ Figure 1. Research framework $>$ here}

The study began with IPD data and reports published by the AIA, National Association of State Facilities Administrators (NASFA), and Associated General Contractors of America (AGC) (e.g. and AIA, 2007b; AIA, 2007a; AIA et al., 2010a). Different studies were then reviewed to evaluate the reliability of data from previous studies. All relevant factors for the implementation of IPD were obtained from AIA reports including Integrated Project Delivery: Case studies (AIA, 2010b), and other practical factors were included from industrial project case studies and academic literature. Based on the data, several unique factors to Korea were included based on practical conditions in the Korean construction sector. 
175 A total of 60 potential factors were obtained and used to conduct semi-structured interviews 176 with 13 Korean construction experts to develop a questionnaire and ensure clarity and 177 relevance. The interview respondents are in senior managing positions or higher in their 178 organizations and have an average of over 16.5 years of work experience in the construction 179 industry. Using their empirical experience and expertise, they reviewed the different essential 180 prerequisites potential IPD factors to determine the most influential ones. They also and 181 determined three dependent variables that are the least or most critical for a successful 182 application of IPD in the Korean construction industry. These three dependent variables indispensable conditions were analyzed using were collected from different references (Middlebrooks, 2008; Kent and Becerik-Gerber, 2010; Raisbeck, et al., 2010) were discussed and finally chosen by semi-structured interviews. seven factor clusters (FCs) (see Table VI).

Pilot surveys were used to gather comments and suggestions for the survey items, item wording, item sequence, and directions. The questionnaires were distributed to different Korean construction experts comprising key personnel in client organizations (such as owners), architects, consulting practices, and construction and engineering firms. All respondents were selected from registered members of the Construction Association of Korea, which is supported by the government and is the largest construction organization in Korea.

The structure of the questionnaire was divided into two main parts. Part 1 included six general questions to acquire general information and determine the overall recognition of IPD in the Korean construction industry. In part 2, the respondents were asked to rate all the potential IPD success factors and to suggest ways in which introducing and implementing IPD could be successful in Korea. We used a five-point Likert scale (ranging from $1=$ strongly disagree to $5=$ strongly agree). The responses were used to determine how critical individual IPD factors would be in implementation. Statistical analyses were carried out on the results using the Statistical Package for Social Sciences (SPSS).

Factor analysis is an advanced statistical technique that is used to examine the underlying patterns or relationships of a large number of variables and to determine whether the exhaustive list of variables can be condensed or summarized with a smaller set of explainable components (Norusis, 2012). This is useful when representing relationships involving numerous interrelated components. Factor analysis was mainly used to categorize and reduce the initial 60 IPD factors 
205 to a more manageable number of CSFs. The factors were extracted and rotated to obtain a 206 minimum quantity of aspects and acquire an accurate understanding of what is represented by 207 the factors.

208 Based on the results of factor analysis, a multiple regression analysis was performed to test 209 the relationship between on the seven factor clusters (FCs; independent variables) FCs and 210 three prerequisites (dependent variables) for a successful application of IPD. to analyze the 211 contributions of individual factors to IPD introduction. The results show the independent

212

213

214

215

216

217

218

219

220

221

222

223

224

225

226

227

228

229

230

231

232

233 variables (FCs) showed which CSFs are positively related to successful IPD introduction in Korea that have a positive correlation with dependent variables (three prerequisites for IPD) according to the beta coefficient and $t$-test. This study hypothesizes that successful FCs (independent variables) should satisfy the prerequisites (dependent variables). Thus, only FCs that have significant correlation with three prerequisites (dependent variables) will be recognized as CSFs for IPD application. Multiple regression analysis indicated correlations between the seven FCs (independent variables) and three successful application conditions (dependent variables).

\section{DATA COLLECTION AND ANALYSIS}

\subsection{Data collection}

During data collection, 362 questionnaires were distributed to Korean construction experts by e-mail or in person. A total of 118 valid responses (approximately $32 \%$ ) were received for data analysis. The responders consisted of 14 clients, 22 architects, 32 general contractors, 13 project managers, 10 construction engineers, 9 manufacturers and suppliers, 6 project inspectors, 9 academic or research institutions, and 3 other engineers, as summarized in Table I.

\section{Insert $<$ Table I . Information from respondents to a questionnaire survey $>$ here}

As shown in Table $\Pi$, the success factors of IPD are ranked in order of agreement according to their mean values. The mean values and standard deviations of each factor were derived 
234 from the total sample to determine the level of agreement. Mean values that are greater than 235 the average value of all factors (3.129) are recognized as critical. Finally, 29 factors among the 236 initial 60 items were determined as critical for IPD implementation. The 29 selected IPD factors 237 were categorized into 7 FCs using factor analyses. After multiple regression analyses, four 238 CSFs for IPD were determined among seven IPD FCs, as shown in Figure 2.

239

240

241

\section{Insert < Table ㅍ. Respondents' ratings of IPD success factor $>$ here}

\section{Insert $<$ Figure 2. Analysis procedures to identify CSFs $>$ here}

\subsection{Factor analysis}

Factor analysis is a series of methods for identifying groups of related variables, and it is an ideal technique for reducing numerous items into a more easily understood framework (Norusis, 2012). Factor analysis was applied to explore the data groupings. The 29 selected IPD factors were subjected to factor analysis using SPSS 22.0. For reliable factor analysis, the Bartlett test of sphericity and the Kaiser-Meyer-Olkin (KMO) measure of sampling adequacy were used.

\section{Insert $<$ Table III. Results of Bartlett's test and KMO measure $>$ here}

As shown in Table II , the result of the Bartlett test was 617.036, and the associated significance level was 0.000 . All variables had a significant correlation of at least $5 \%$. This implies that no other variables need to be excluded from the analysis. The KMO measure of sampling adequacy is 0.742 , and since it is higher than 0.5 , the samples meet the fundamental requirement for factor analysis (Norusis, 2012).

\section{Insert < Fable-IV. Final-statistic of principal component analysis $>$ here}


As shown in Table IV, shows the final statistics of the principal component analysis (PCA),

262

263

264

265

266

267

268

269

270

271

272

273

274

275

276

277

278

279

280

281

282

283

284

285

286

287

288

in which the seven extracted FCs comprise $58.45 \%$ of the variance. The varimax rotation of PCA was used to interpret the FCs. as shown in Table $V$. Each IPD success factor belongs to one of the seven FCs, and the loading on each factor exceeds 0.60 . Only 23 of the 29 IPD factors were clustered into the seven FCs. The varimax rotation result of six factors was less than 0.60. The seven FCs and their relevant features are labeled as follows:

FC 1: Reform of the contract law and adoption of appropriate IPD agreement form.

FC 2: Team building and management for collaborative business process.

FC 3: Intensified planning and management from early project stage.

FC 4: Early involvement and enhanced role of key participants.

FC 5: Mutual respect and trust with government support.

FC 6: Improvement and utilization of BIM for collaborative process of IPD.

FC 7: PMIS for collaborative decision making and a networked sharing system.

Insert $<$ Table IV. $\vee$. Component analysis and matrix after varimax rotation $>$ here

\subsection{Correlation analysis}

Correlation analysis was conducted to investigate the relationships between independent variables (the seven FCs) and dependent variables determined from the interviews, as shown in Table VI. Three dependent variables were recognized as fundamental criteria when deciding whether the seven analyzed FCs are critical for IPD implementation in Korea.

\section{Insert < Table VI. Results of correlation analysis $>$ here}

The correlation analysis results show that there is a significant positive correlation between the dependent variables and seven FCs. "Impact of IPD adoption on overall construction industry" was correlated with five independent variables (FC1, FC2, FC4, FC5, and FC7), "Understanding and experience about IPD system" was correlated with four independent 
variables (FC1, FC2, FC5, and FC7), and "Synergy effect between IPD and BIM" was

290

significantly correlated with five independent variables (FC1, FC2, FC4, FC5, and FC7).

291

292

\subsection{3 Multiple regression analysis}

293

Stepwise multiple regressions were carried out to test how much correlation between the three dependent variables and seven FCs as independent variables using SPSS 22.0. In 295 accordance with the hypothesis of this study in which only successful independent variables 296 (FCs) will be recognized as the SCFs for implementation of IPD in Korea, 7 FCs were analyzed to see how significant correlation were with three dependent variables using multiple regression analysis. Since the purpose of this study is not to recognize whether a certain 299 independent variable may become the CSF but to recognize what independent variables can be CSFs for IPD implementation, multiple regression analysis was used to find out multiple CSFs.

Table V $\quad$ II shows the standardized regression coefficient $(\beta)$, standard significance $(p)$, 302 coefficient of determination (R2), adjusted R-square value (Adjusted $\mathrm{R}^{2}$ ), and variation in the $\mathrm{R}$-square value $\left(\Delta \mathrm{R}^{2}\right)$. The size of the sample used in the final outcome is 118 . Among the seven independent variables, only four (FCs), were analyzed with a significant correlation showing the differences from 0.000 at $\mathrm{p} \leq 0.04$ : "Reform of the contract law and adoption of appropriate IPD agreement form” (CF1), “Team building and management for collaborative 307 business process" (CF2), "Early involvement and enhanced role of key participants" (CF4), 308 and "Improvement and utilization of BIM for collaborative process of IPD" (CF7).

\section{Insert $<$ Table V VII. Multiple regression result $>$ here}

311

These four independent variables (CSF1, CSF2, CSF3, CSF4) (CSFs) altogether explained $60.7 \%\left(R^{2}=0.607\right)$ of the variance of the three dependent variables (Table $\left.\mathrm{V} \forall \mathrm{Z}\right)$. Among the four CSFs identified, "Reform of the contract law and adoption of appropriate IPD agreement form" is the strongest CSF, which accounted for $31.5 \%$ of the total explanation $\left(\mathrm{R}^{2}=0.315, \mathrm{p}\right.$ $\leq 0.001)$. This result indicates that IPD can be implemented successfully in Korea if contract 
317 law is reformed and an appropriate IPD agreement form is adopted. "Team building and 318 management for collaborative business process" (CSF 2), "Early involvement and enhanced 319 role of key participants" (CSF 3), and "Improvement and utilization of BIM for collaborative 320 process of IPD" (CSF 4) account for 29.6\%, 14.3\%, and 2.5\% of the explanation for the overall 321 implementation success of IPD, respectively.

322

\section{RESEARCH FINDINGS}

324

325

326

327

328

329

330

331

332

333

334

335

336

337

338

339

340

341

342

343

344

345

346

In this section, the identified CSFs are further described in terms of their practical meaning and usefulness.

\subsection{CSF 1: Reform of contract law and adoption of appropriate IPD agreement form (FC 1).}

CSF 1 consists of three IPD factors (F01, F04, and F05) and accounts for $31.5 \%$ of the total variance explained. CSF 1 accounts for the largest part, which is greater than those of the rest of the three CSFs combined. This means that the most critical factor in applying IPD to the Korean construction industry is law amendments and active commitment by the government, at least for public government projects.

BIM-based projects and public-private partnership (PPP) are now very common in Korea, but they were all initially applied and adapted to the market led by the government. Compared to the construction industries in developed countries such as the UK and US, the Korean construction industry is smaller and simpler, so there are limitations on creating and developing innovative systems in the private sector (Lee and Lee, 2009). Whenever new systems such as BTL, Design-Build, and PPP are launched in Korea, they are first applied in public projects led by the government. Thus, the role of the government is crucial in the Korean construction industry.

National contract law should be amended to implement an IPD system in Korea practically. In addition, there is no practical IPD agreement form in Korea, so the US IPD form created by the AIA (2010) could be adapted to the Korean construction industry's needs. The probability of successful IPD implementation in Korea will increase if the government could set up explicit guidelines to reform Korean law or if it could accept adapted IPD forms from abroad. 
3475.2 CSF 2: Team building and management for collaborative business process (CF 2).

348 CSF 2 comprises three IPD factors (F17, F22, and F27), all of which are relevant to appropriate 349 team building and management for a collaborative business process. CSF 2 accounts for 13.3\% 350 of the total variance (the second largest). In traditional procurement in Korea, contractors tend 351 to have more responsibility than any other project participant throughout all project stages. 352 This occurs because all participants tend to rely on the contractor's technology, experience, 353 knowledge, equipment, and capital for the sake of efficiency (Sachs et al., 2004; Cho and 354 Chung, 2011). Thus, an explicit definition of the work scope and responsibility (F22) can 355 make an IPD project seem more reliable and clear to potential participants (El Asmar, 2012; 356 Zhang et al., 2013). By using this definition, contractors can expect the risk they normally bear 357 to be shared, and other project participants can easily access advanced technologies, 358 information, and other benefits through active involvement.

359 The increasing authority and role of independent project managers (F17) and developing an 360 IPD business process model (F27) can help to manage IPD projects with a collaborative 361 business model in target project performance. In all project stages, particularly in the 362 construction process, each team member such as a supplier or architect has a different purpose 363 and interest in the project according to their economic situation and business area (Asmar et 364 al., 2013; Monteiro et al., 2014). These differences are likely to make the project more 365 complicated and difficult to manage. However, if a project manager has authorized leadership 366 and a successful reference model, the project can be successful while applying the IPD model 367 in the construction industry within a short period of time.

368

5.3 CSF 3: Early involvement and enhanced role of key participants (FC 4).

370 There are two IPD factors (F20, F21) involved in CSF 3, which is responsible for 9.1\% of the 371 total variance. IPD is an approach for maximizing a project's value by collaboration, risk and 372 benefit sharing, and mutual respect between project participants from the initial stage (Song et 373 al., 2011). The involvement of the contractors in the design process and architects in the 374 construction process (F21) indicate the changing role of all project participants and make the 375 project more flexible. Thus, the construction industry can be changed to a more favorable 376 environment to apply IPD (Lee et al., 2012). However, if key project participants including 377 clients and architects do not have enough competence to adapt to the different roles, acceptance 
378 of the changing roles may become the biggest constraint on project success and the ability to

379 implement IPD at an early project stage.

380

381

5.4 CSF 4: PMIS for collaborative decision-making and networked sharing system (FC 7).

382 There are three success factors (F47, F49, F60) involved in CSF 4, which is responsible for 7.0\%

383 of the total variance. In Korea, contractors usually use their own information management

384 system specified by the PMIS. PMIS can be defined as a web-based database that centralizes

385 information and represents specific data from the project, as well as non-geometric information

386 (Thomsen et al., 2010). In IPD systems, knowledge and information sharing is recognized as

387 the most basic and critical factor because without it, the core values of IPD cannot be realized,

388 such as collaboration and integration between participants. Thus, the capacity of IPD team

389 members supported by various technologies is critical, including BIM, PMIS, and other

390 collaboration tools (F49). These IT technologies (BIM or PMIS) can transfer and restore

391 information and knowledge systematically. Fortunately, the Korean construction industry is

392 already a favorable environment for projects based on IT technologies (Kim, 2005; Suh et al.,

393 2013). These conditions are favorable for applying IPD systems in Korea.

394

395

\section{CONCLUSION}

396

397

An extensive analysis was conducted on IPD systems in the Korean construction sector. We developed an outline of data taken from academic and industrial sectors that highlight key 398 components for successful implementation of IPD. Questionnaires were used to collect local knowledge and personal viewpoints on how an IPD system could be successfully implemented.

400 Among the 60 initial IPD factors, 29 were selected for further investigation through a 401 questionnaire survey. The extracted IPD factors were categorized into seven FCs based on a 402 factor analysis. Finally, using multiple regression analysis, four of the FCs consisting of several 403 IPD factors were identified as CSFs in the implementation of IPD systems.

404 Our findings could be used as framework of reference to measure the success of IPD projects. 405 They could also provide useful guidelines for project stakeholders who are considering IPD 406 projects. The findings indicate that these CSFs could strongly influence the implementation of 407 IPD systems in Korea. In addition, developing countries are actively accepting the advantages 
408 of managing systems such as BIM and PMIS to enhance their competitiveness in the global 409 market. Thus, the CSFs for IPD in Korea could be applied to other developing or mid-sized 410 construction industries without major reform or technical constraints.

411

\section{7. Acknowledgements}

413 This work was supported by the 2017 Yeungnam University Research Grant. 


\section{References}

416 AIA National and AIA California Council (2007a), Integrated Project Delivery: A Guide, 417 AIA California Council. American Institute of Architects (AIA), Washington, DC. 418 AIA California Council (2007b), Integrated project delivery: A working definition, Retrieved 419 from http://aiacc.org/wp-content/uploads/2010/07/A-Working-Definition-V2$420 \quad$ final.pdf

421 American Institute of Architects (AIA), National Association of State Facilities Administrators (NASFA), Construction Owners Association of America (COAA), Association of Higher Education Facilities Officers and Associated General Contractors of America (AGC) (2010a), Integrated Project Delivery For Public and Private Owners, American Institute of Architects (AIA), Washington D.C.

American Institute of Architects (AIA) (2010b), Integrated project delivery: Case studies, California Council, Sacramento, CA.

Chan, A. P., Chan, D. W., Chiang, Y. H., Tang, B. S., Chan, E. H. and Ho, K. S. (2004),

"Exploring critical success factors for partnering in construction projects", Journal of

Construction Engineering and Management, Vol. 130 No. 2, pp. 188-198.

Cho, S., Ballard, G., Azari, R. and Kim, Y. (2010), "Structuring ideal project delivery 432 System", Proceedings, IPPC4.

Cho, J. H. and Chung, K. R. (2011), Country report: South Korea. CTBUH Journal 2011, Vol. 4, pp. 42-47, Retrieved from http://technicalpapers.ctbuh.org.

\section{Construction Users Roundtable (CURT) (2004), Collaboration, Integrated Information}

and the Project Lifecycle in Building Design, Construction and Operation, Architectural/ Engineering Productivity Committee of The Construction UsersRoundtable (CURT), Cincinnati, OH.

El Asmar, M. (2012), "Modeling and benchmarking performance for the integrated project delivery (IPD) system", Unpublished PhD dissertation, University of WisconsinMadison, US.

El Asmar, M., Hanna, A. and Loh, W. (2013), "Quantifying Performance for the Integrated Project Delivery (IPD) System as Compared to Established Delivery Systems", Journal of Construction Engineering and Management, Vol. 193 No. 11, 04013012. 
445 Forbes, L. H. and Ahmed, S. M. (2011), Modern Construction: Lean Project Delivery and $446 \quad$ Integrated Practices, CRC Press, Boca Raton, FL.

447 Halpin, D. W. (2006), Construction Management, 3rd ed, John Wiley \& Sons, New York, $448 \quad \mathrm{NY}$.

449 Hanna, A. S. (2010), Construction labor productivity management and methods 450 improvement, University of Wisconsin-Madison, Madison, WI.

451 Ilozor, B. D. and Kelly, D. J. (2012), "Building Information Modeling and Integrated 452 Project Delivery in the Commercial Construction Industry: A Conceptual Study", 453 454 455 456 457 458 459 Journal of Engineering, Project, and Production Management, Vol. 2 No. 1, pp. 23-36.

Kent, D. C. and Becerik-Gerber, B. (2010), "Understanding construction industry experience and attitudes toward integrated project delivery". Journal of Construction Engineering and Management, Vol. 136 No. 8, pp. 815-825.

Kim, J. H. (2005), "Effective Application of PMIS through Analysis of Barriers At the Development of PMIS", Journal of the Korea Institute of Building Construction, Vol. 5 No. 4, pp. 107-114 [In Korean].

Lahdenpera, P. (2012), "Making sense of the multi-party contractual arrangements of project partnering, project alliancing and integrated project delivery", Construction Management and Economics, Vol. 30 No. 1, pp. 57-79.

Lee, B. and Lee, J. (2009), “Advancement plan of construction project delivery method”, Korea Journal of Construction Engineering and management, Vol. 48 No. 2, pp. 27-30 [In Korean].

Lee, J., Han, J., Paik, S., Kim, W., Jeon, H. and Choi, K. (2012), “A method for the application of IPD to Domestic Construction Industry through SWOT Analysis", Journal of the Architectural Institute of Korea, Vol. 281 No. 3, pp. 99-106 [In Korean].

Middlebrooks, B. (2008), “Integrated project delivery in practice”, Journal of Structural Engineering, Vol. 9 No. 12, pp. 28-30.

Monteiro, A., Mêda, P. and Poças Martins, J. (2014), "Framework for the coordinated application of two different integrated project delivery platforms", Automation Construction, Vol. 38, pp. 87-99.

Norusis, M. J. (2012), IBM SPSS statistics 19 statistical procedures companion, Prentice Hall. 
476 O’Connor, P. J. (2009), Integrated project delivery: Collaboration through new contract

477

478

479

480

481

482

483

484

485

486

487

488

489

490

491

492

493

494

495

496

497

498

499

500

501

502

503 forms, Faegre \& Benson, Minneapolis.

Raisbeck, P., Millie, R. and Maher, A. (2010), “Assessing integrated project delivery: a comparative analysis of IPD and alliance contracting procurement routes”. In: Egbu, C. (Ed) Procs 26th Annual ARCOM Conference, 6-8 September 2010, Leeds, UK, Association of Researchers in Construction Management, 1019-1028.

Sachs, T., Kong, T. L. and Koo, J. K. (2004), "Establishment of foreign construction companies in Korea and the Korean construction industry in a foreign perspective: An industry analysis for market entry", International Symposium on Globalisation and Construction, AIT Conference, Bangkok, Thailand, 17-19 November, pp. 421-431.

Song, S., Kim, Y., Chin, S. an"d Kwon, S. (2011), “An Analysis on the Perception of Domestic Construction Engineer to Introduce IPD”, Korean Journal of Construction Engineering and Management, Vol. 12 No. 2, pp. 72-80 [In Korean].

Suh, B. G., Lee, G. and Yun, S. H. (2013), “Adoption of Virtual Technology to the Development of a BIM based PMIS”, Journal of the Korea Institute of Building Construction, Vol. 13 No. 4, pp. 333-340.

Swarup, L., Korkmaz, S. and Riley, D. (2011), "Project Delivery Metrics for Sustainable, High-Performance Buildings", Journal of Construction Engineering and Management, Vol. 137 No. 12, pp. 1043-1051.

Thomsen, C. (2009), Integrated Project Delivery: An Overview, US. CMAA.

Thomsen, C., Darrington, J., Dunne, D. and Lichtig, W. (2010), Managing Integrated Project Delivery, Construction Management Association of America. Mclean, VA.

Volk, R., Stengel, J. and Schultmann, F. (2014), "Building Information Modeling (BIM) for existing buildings: Literature review and future needs", Automation in Construction, Vol. 38, pp. 109-127.

Zhang, L., He, J. and Zhou, S. (2013), “Sharing tacit knowledge for integrated project team flexibility: case study of integrated project delivery", Journal of Construction Engineering and Management, Vol. 139 No. 7, pp. 795-804. 


\section{Figure Caption List}

Figure 1. Research framework

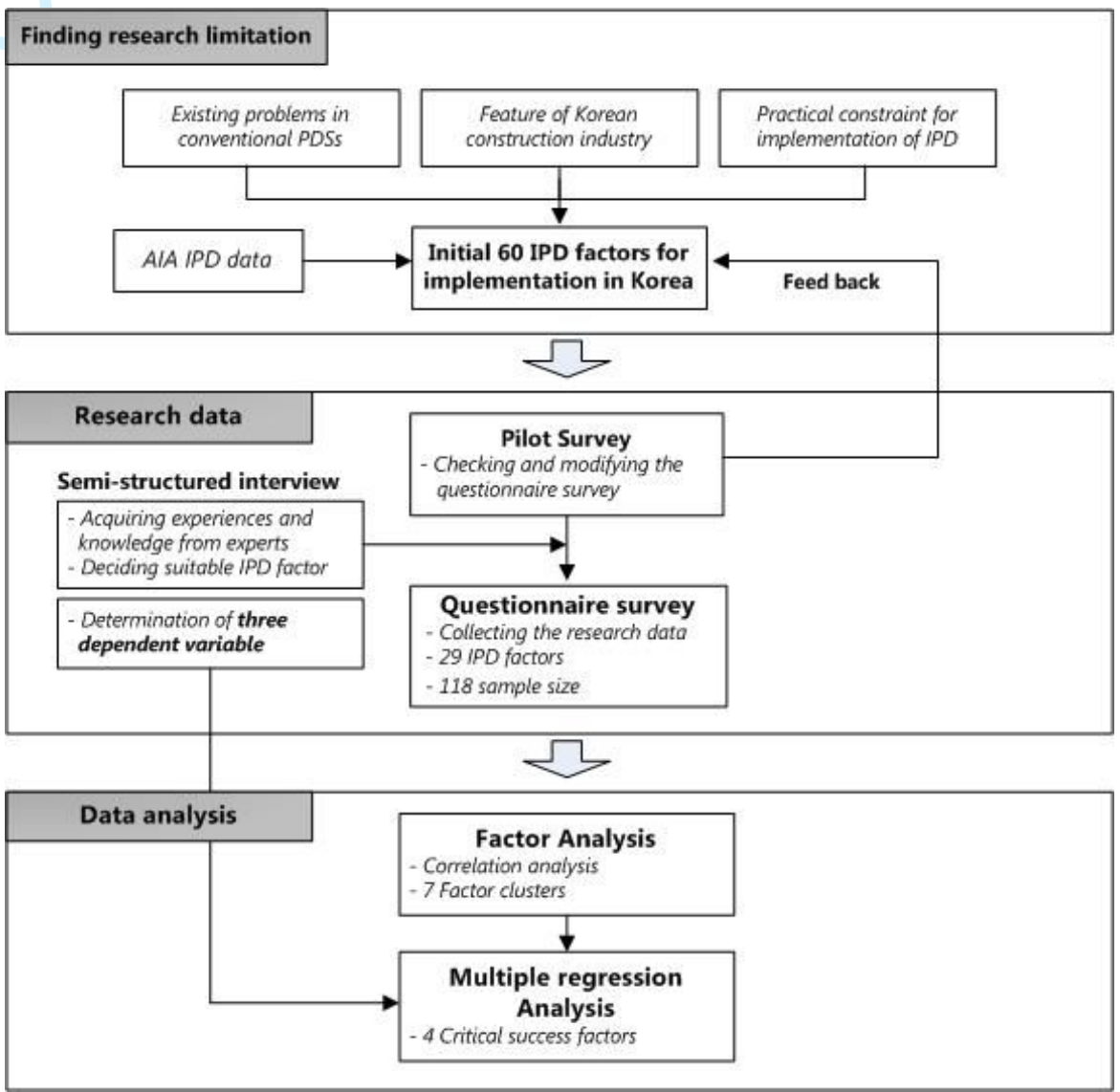


Figure 2. Analysis procedures to identify CSFs

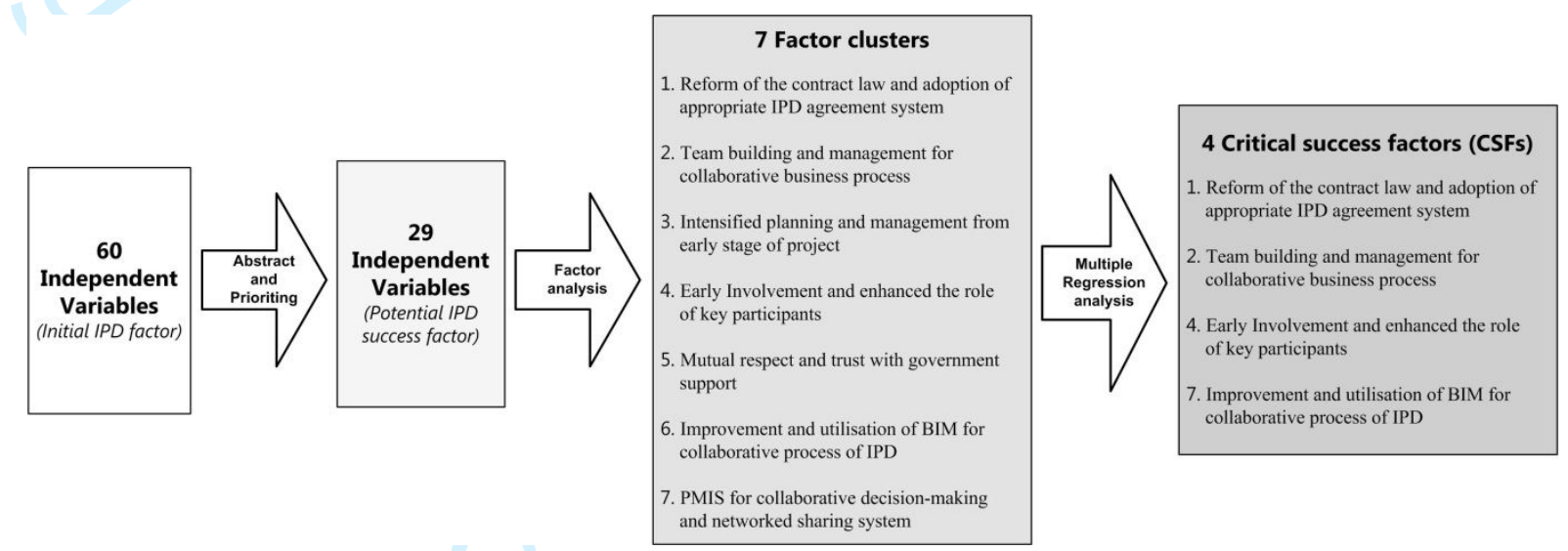




\section{Table Caption List}

Table 1 Information from respondents to a questionnaire survey

Table 2. Respondents' ratings of IPD success factor

Table 3. Results of Bartlett's test and KMO measure

Table 4. Component analysis and matrix

Table 5. Multiple regression result 
Table 1. Information from respondents to a questionnaire survey

\begin{tabular}{|c|c|c|c|}
\hline Respondents & Contents & Frequency & Percentage (\%) \\
\hline \multirow{10}{*}{ Occupation } & Owner (client) & 14 & 11.86 \\
\hline & Architect & 22 & 18.64 \\
\hline & General contractor & 32 & 27.12 \\
\hline & Project manager & 13 & 11.02 \\
\hline & Construction engineer & 10 & 8.47 \\
\hline & Manufacturer/supplier & 9 & 7.63 \\
\hline & Project inspector & 6 & 5.08 \\
\hline & Working in academic or research institutions & 9 & 7.63 \\
\hline & Others & 3 & 2.55 \\
\hline & Total & 118 & 100.00 \\
\hline \multirow{6}{*}{$\begin{array}{l}\text { Present career } \\
\text { experience }\end{array}$} & Less than 3 years & 20 & 16.95 \\
\hline & 3 to 5 years & 27 & 22.88 \\
\hline & 6 to 10 years & 44 & 37.29 \\
\hline & 11 to 15 years & 16 & 13.56 \\
\hline & More than 15 years & 11 & 9.32 \\
\hline & Total & 118 & 100.00 \\
\hline
\end{tabular}

http://mc.manuscriptcentral.com/ecaam 
Table 2. Respondents' ratings of IPD success factor

\begin{tabular}{|c|c|c|c|c|}
\hline Succe & s factor of IPD & Mean & $\begin{array}{l}\text { Standard } \\
\text { deviation }\end{array}$ & Ranking \\
\hline F57 & Developing customized IPD business process involving BIM technology. & 3.706 & 1.108 & 1 \\
\hline F05 & Introducing multi-party agreement. & 3.701 & 0.958 & 2 \\
\hline F21 & Direct involvement of contractors and engineers in the design phase. & 3.688 & 0.921 & 3 \\
\hline F39 & $\begin{array}{l}\text { Introducing IPD system to public projects with IT vitalization policy by the } \\
\text { government. }\end{array}$ & 3.657 & 0.933 & 4 \\
\hline F11 & Establishing risk sharing system between team members. & 3.611 & 1.218 & 5 \\
\hline $\mathrm{F} 22$ & Defining work scope and responsibility between team members. & 3.609 & 1.112 & 6 \\
\hline F47 & $\begin{array}{l}\text { Developing decision making system for the participation of all team members to } \\
\text { contribute their expertise. }\end{array}$ & 3.590 & 0.984 & 7 \\
\hline F04 & $\begin{array}{l}\text { Establishing standard IPD contract form considering Korean construction } \\
\text { environment. }\end{array}$ & 3.558 & 1.191 & 8 \\
\hline F60 & $\begin{array}{l}\text { Developing and operating project management information system (PMIS) based } \\
\text { on business process of IPD. }\end{array}$ & 3.547 & 1.103 & 9 \\
\hline $\mathrm{F} 27$ & $\begin{array}{l}\text { Developing IPD business process model for collaborative work between team } \\
\text { members. }\end{array}$ & 3.524 & 1.020 & 10 \\
\hline F49 & $\begin{array}{l}\text { Capacity of IPD team members to fully utilize IPD supporting IT such as BIM or } \\
\text { PMIS. }\end{array}$ & 3.523 & 1.003 & 11 \\
\hline F37 & $\begin{array}{l}\text { Reforming relationships from the vertical to horizontal among key project } \\
\text { participants. }\end{array}$ & 3.513 & 0.981 & 12 \\
\hline F45 & Establishing expected project benefit through the implementation of IPD project in & 3.511 & 0.958 & 13 \\
\hline
\end{tabular}


Korean construction sector.

Improving motivation and teamwork between IPD team members from initial project

F33 stage.

F01 Reforming national contract law and amending IPD agreement form.

Developing integrated real-time information and document sharing system with cloud system.

F06 Reforming unfair contract structure and practice (especially, design contract). Vitalizing the construction management (CM/PM) to support client who suffers

F42 from increasing workload and lack expert knowledge in IPD system.

Increasing authority and role of independent project manager to organize and coordinate IPD team

F30 Training experts to support IPD project from the early project stage.

F26 Determining the design changes and disputable factors from early project stage. Establishing work process and data transfer system between IPD team and IT system (BIM or PMIS).

Improving communication and collaboration between team members through the 3 $\mathrm{D} / 4 \mathrm{D}$ visualization and modeling technology.

Enhancing supply chain management plan among key participants from design phase.

F20 Changing the role of owner (government) in public construction projects.

F28 Fully trust and mutually respect other industry team members as one team. Developing official guideline on the implementation of IPD by a government initiative

F35 Quick organization of IPD team at the early project stage. 


\section{Table 3. Results of Bartlett's test and KMO measure}

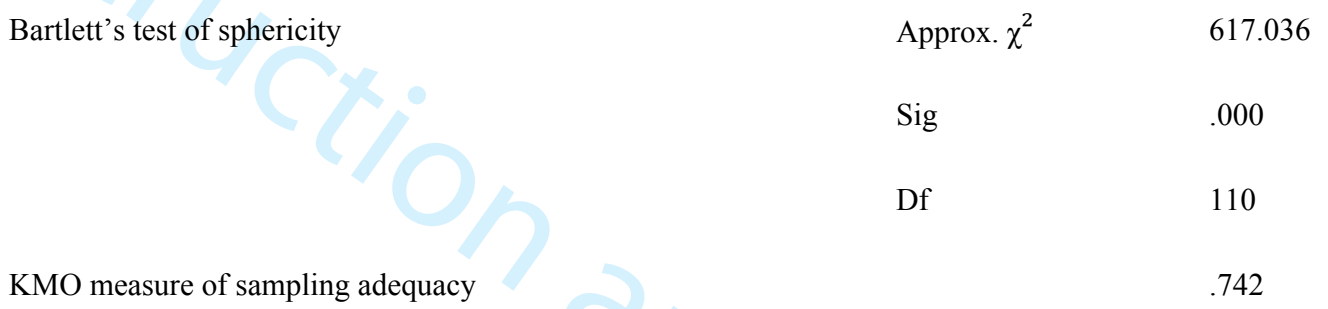

http://mc.manuscriptcentral.com/ecaam 
Table 4. Component analysis and matrix

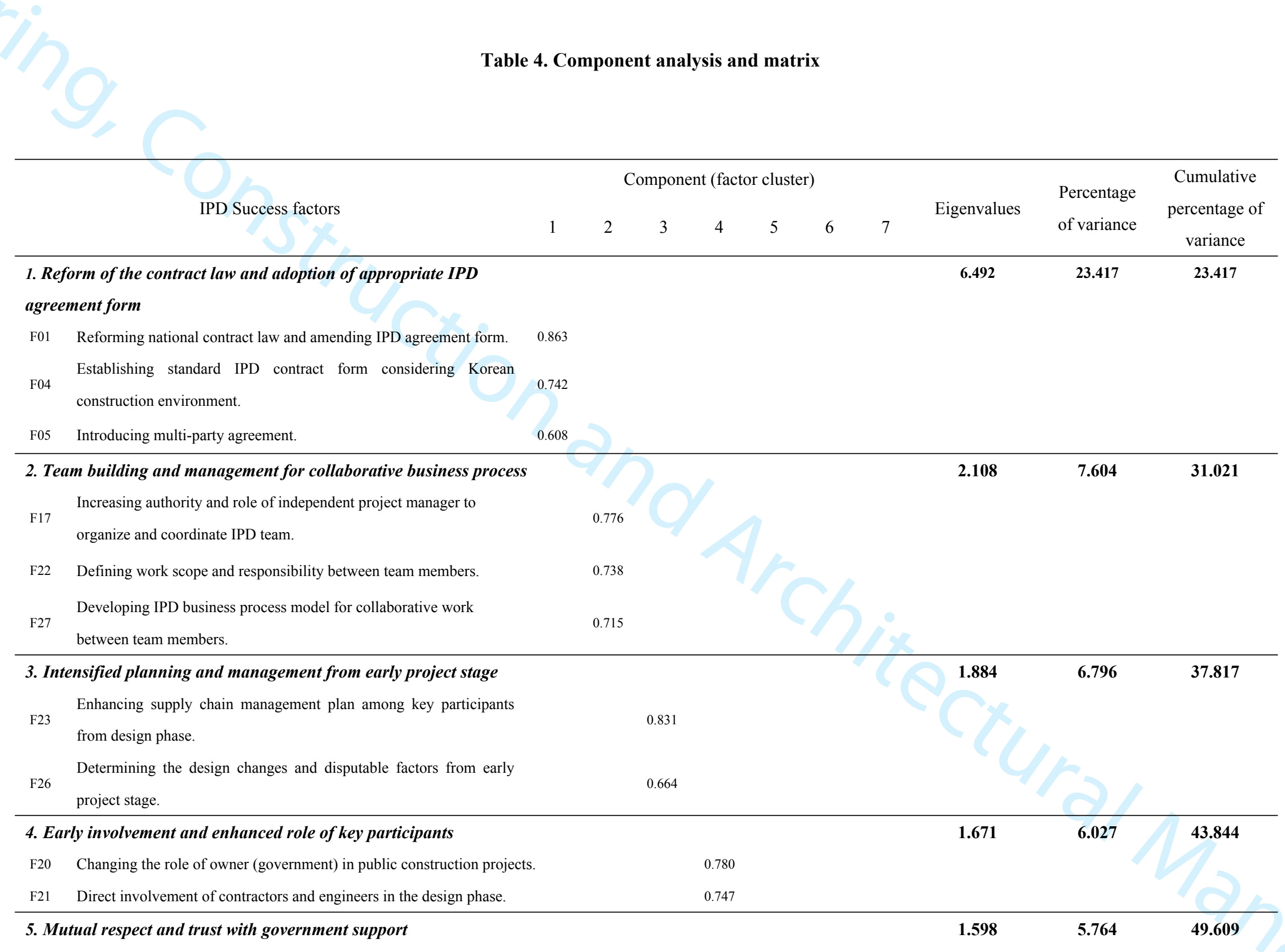


F28 Fully trust and mutual respect other industry team members as one team.

Improving motivation and teamwork between IPD team members

F35 Quick organization of the IPD team at the early project stage

Reforming relationships from the vertical to horizontal among key

F37

project participants.

Developing official guideline on the implementation of IPD by a

F4

government initiative

Vitalizing the construction management (CM/PM) to support client who

suffers from increasing workload and lack expert knowledge in IPD system.

\section{Improvement and utilization of BIM for collaborative process of IPD}

1.332

4.805

54.413

Developing integrated real-time information and document sharing system with cloud system.

Improving communication and collaboration between team members

F55 through the $3 \mathrm{D} / 4 \mathrm{D}$ visualization and modeling technology.

Establishing work process and data transfer system between IPD team

F56 and IT system (BIM or PMIS)

F57 Developing customized IPD business process involving BIM technology.

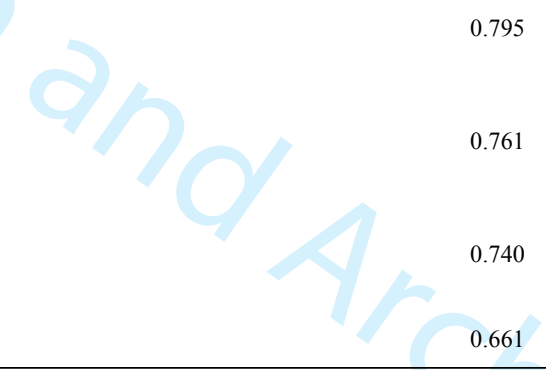

7. PMIS for collaborative decision-making and networked sharing system

F47 Developing decision making system for the participation of all of team members to contribute their expertise.

F49 Capacity of IPD team members to fully utilize IPD supporting IT such as BIM or PMIS.

Developing and operating project management information system (PMIS) based on business process of IPD.

Extraction method: Principal component analysis.

Rotation method: Varimax with Kaiser normalization.

Rotation converged in seven iterations.
1.120

4.040

58.453

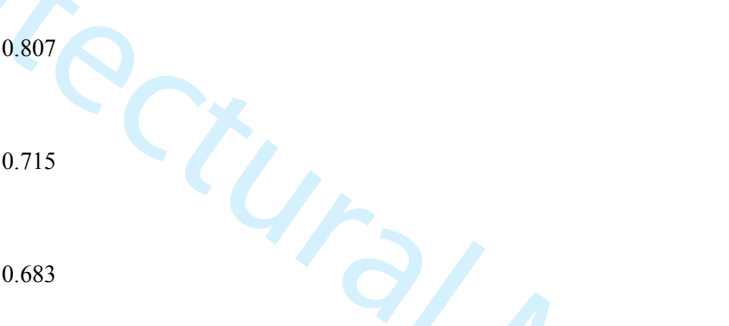


Table 5. Multiple regression result

\begin{tabular}{|c|c|c|c|c|c|c|c|c|c|}
\hline \multicolumn{2}{|c|}{$\begin{array}{l}\text { Independent } \\
\text { Variables (FCs) }\end{array}$} & $\begin{array}{c}\text { Impact of IPD } \\
\text { adoption on overall } \\
\text { construction } \\
\text { industry }\end{array}$ & $\begin{array}{l}\text { Understanding } \\
\text { and experience } \\
\text { about IPD system }\end{array}$ & $\begin{array}{c}\text { Synergy effect } \\
\text { between IPD } \\
\text { and BIM }\end{array}$ & $\beta$ & $\mathrm{p}$ value & $\mathrm{R}^{2}$ & Adjusted $\mathrm{R}^{2}$ & ${ }_{\Delta} \mathrm{R}^{2}$ \\
\hline CSF 1 & $\begin{array}{l}\text { Reform of the contract law and adoption of } \\
\text { appropriate IPD agreement form (F01, F04, F05). }\end{array}$ & $.455^{\text {** }}$ & $.332^{* *}$ & $.489^{* *}$ & .527 & .000 & .315 & .294 & .315 \\
\hline \multirow[t]{2}{*}{ CSF 2} & $\begin{array}{l}\text { Team building and management for collaborative } \\
\text { business process (F17, F22, F27). }\end{array}$ & $.329^{* *}$ & $.473^{* *}$ & $.389^{* *}$ & .421 & .000 & .448 & .411 & .296 \\
\hline & $\begin{array}{l}\text { Intensified planning and management from early } \\
\text { project stage (F23, F26). }\end{array}$ & .163 & -.092 & -.024 & & & & & \\
\hline \multirow[t]{2}{*}{ CSF 3} & $\begin{array}{l}\text { Early involvement and enhanced role of key } \\
\text { participants (F20, F21). }\end{array}$ & $.415^{\text {** }}$ & .139 & $.239^{*}$ & .380 & .001 & .539 & .497 & .143 \\
\hline & $\begin{array}{l}\text { Mutual respect and trust with government support } \\
\text { (F28, F33, F35, F37, F41, F42). }\end{array}$ & $.394^{* *}$ & $.274^{*}$ & $.328^{* *}$ & & & & & \\
\hline \multirow[t]{2}{*}{ CSF 4} & $\begin{array}{l}\text { Improvement and utilization of BIM for } \\
\text { collaborative process of IPD (F54, F55, F56, F57). }\end{array}$ & .077 & .054 & .188 & .294 & .002 & .607 & .581 & .025 \\
\hline & $\begin{array}{l}\text { PMIS for collaborative decision-making and } \\
\text { networked sharing system (F47, F49, F60). }\end{array}$ & $.323^{* *}$ & $.447^{* *}$ &. $\mathbf{3 3 3}^{* *}$ & & & & & \\
\hline
\end{tabular}

**Correlation is significant at the 0.01 level (2-tailed).

*Correlation is significant at the 0.05 level (1-tailed). 
First of all, thanks for the comments from the Editor and particular a very supportive from all reviewers. Please find our responses to the rest of the comments that are useful for improving the quality of the manuscript.

\section{- Reviewer \#1}

\begin{tabular}{|l|l|l|}
\hline \multicolumn{1}{|c|}{ Review comment } & Description of review comment & In the text the authors added to the paper in response \\
\hline $\begin{array}{l}\text { Very well written paper with good discussion on } \\
\text { findings. }\end{array}$ & & \\
\hline
\end{tabular}

\section{- Reviewer \#2}

\begin{tabular}{|l|l|l|}
\hline \multicolumn{1}{|c|}{ Review comment } & Description of review comment & $\begin{array}{l}\text { Revised parts in the manuscript according to reviewer's } \\
\text { comment }\end{array}$ \\
\hline & & $\begin{array}{l}\text { (Line 15-17) } \\
\text { Due to inereasing project complexity, construetion projects } \\
\text { are carried out both separately and independently using } \\
\text { various systems of delivery. For increasing large and } \\
\text { complex construction projects to be carried out efficiently, a } \\
\text { collaborative execution process needs to be..... }\end{array}$ \\
$\begin{array}{l}\text { Abstract should be more comprehensive..you have 2 } \\
\text { types of analysis, factor and regression. The most } \\
\text { significant finding should be from regression analysis. } \\
\begin{array}{l}\text { Abstract should reveal the significant findings and } \\
\text { implication of study. }\end{array}\end{array}$ & $\begin{array}{l}\text { As reviewer's comment, we elaborate the } \\
\text { significant finding from the regression } \\
\text { analysis and their implications of study in } \\
\text { abstract. }\end{array}$ & $\begin{array}{l}\text { (Line 23-36) } \\
\text { A multiple regression analysis shows that four of the seven } \\
\text { CSFs have significant correlations with the research } \\
\text { findings. four factors are essential among seven CSFs to } \\
\text { implement IPD systems. They are 'Reform of contract law } \\
\text { and adoption of appropriate IPD agreement form (CSF 1)', }\end{array}$ \\
\hline
\end{tabular}




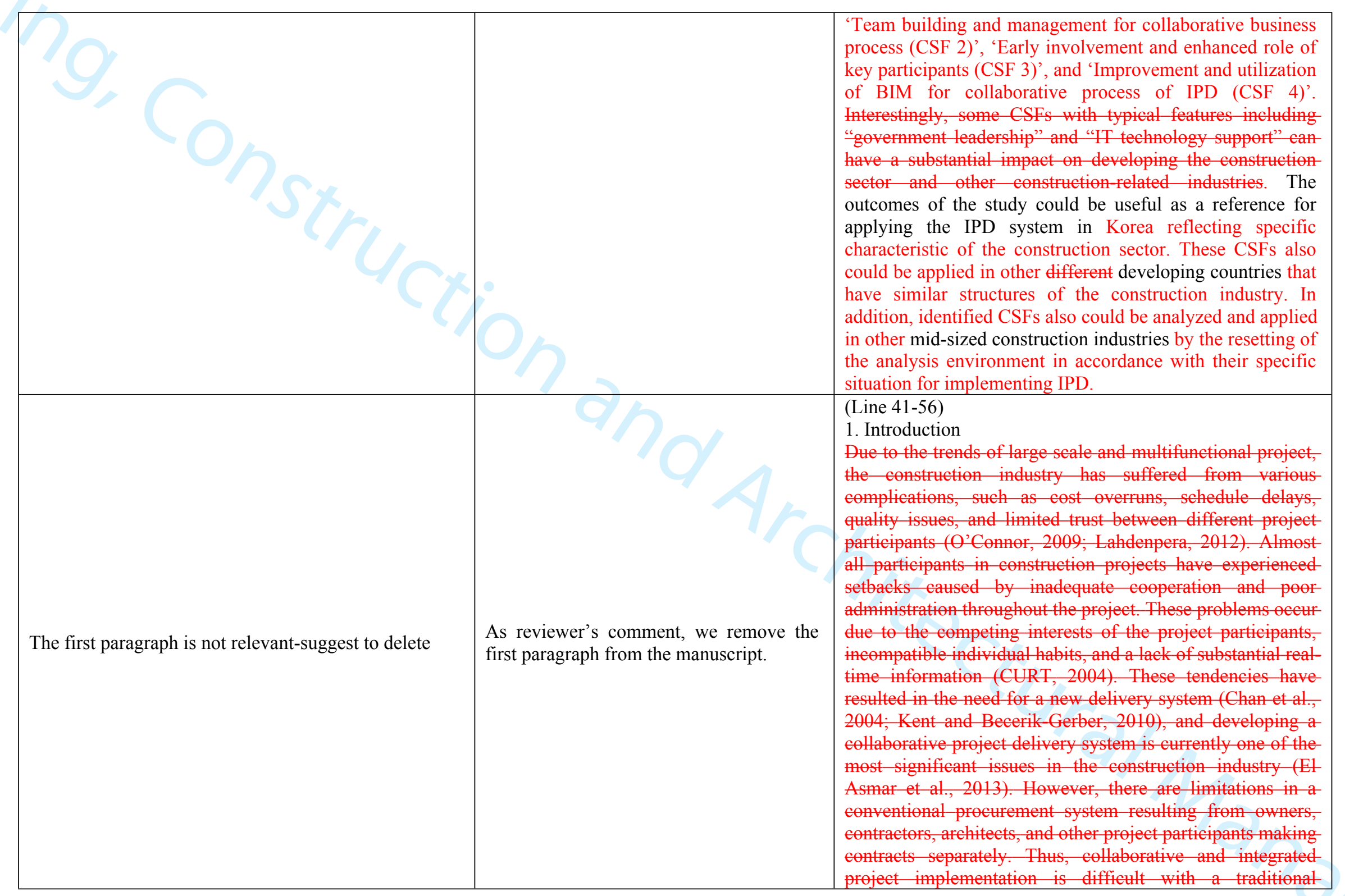




\begin{tabular}{|c|c|c|}
\hline & & $\begin{array}{l}\text { procurement method due to a lack of project continuity and } \\
\text { information sharing. } \\
\text { The American Institute of Architects (AIA) launched the } \\
\text { integrated project delivery (IPD)... } \\
\text { (Line 427-429) } \\
\text { Chan, A. P., Chan, D. W., Chiang, Y. H., Tang, B. S., Chan, } \\
\text { E. H. and Ho, K. S. (2004), "Exploring critical success- } \\
\text { factors for partnering in construction projects", Journal of } \\
\text { Construction Engineering and Management, Vol. } 130 \text { No. 2, } \\
\text { pp. 188-198. } \\
\text { (Line 434-437) } \\
\text { Eonstruction Users Roundtable (CURT) (2004), } \\
\text { Collaboration, Integrated Information and the Project } \\
\text { Lifecycle in Building Design, Construction and Operation, } \\
\text { Architectural/ Engineering Productivity Committee of The- } \\
\text { Construction Users Roundtable (CURT), Cineinnati, OH. }\end{array}$ \\
\hline $\begin{array}{l}\text { Page 3, line } 62 \text { : 'In addition, IPD is still in the test stage } \\
\text { in developing construction sectors such as South } \\
\text { Korea'-this sentence need more explanation. }\end{array}$ & $\begin{array}{l}\text { As reviewer's comment, we elaborated } \\
\text { why IPD is still in the test stage in } \\
\text { developing construction sector including } \\
\text { South Korea. }\end{array}$ & $\begin{array}{l}\text { (Line 69-79) } \\
\text { In addition, IPD is still in the test stage in developing } \\
\text { construction sectors such as South Korea, and there is a lack } \\
\text { of information on actual plans for applying IPD. Since the } \\
\text { IPD was invented assuming the collaboration of the } \\
\text { individual construction parts for a single project from early } \\
\text { stage as a one team, it is highly likely that it will be } \\
\text { successful in an overall fully matured and experienced built } \\
\text { environment. For countries including South Korea that still } \\
\text { do not have enough competency in soft skill such as contract } \\
\text { management or risk management, there is careful research } \\
\text { and practical feedback needed. However, there are still not } \\
\text { many actual project cases even in a country in which IPD } \\
\text { has been developed. Thus, determining the critical success } \\
\text { factors (CSFs) is necessary to introduce IPD successfully. It } \\
\text { is also necessary to determine the kinds of projects where it } \\
\text { is more difficult or impossible to apply IPD. }\end{array}$ \\
\hline Page 4 , line $93 .$. what is relational contracts? & $\begin{array}{l}\text { As reviewer's comment, we elaborate the } \\
\text { meaning to relational contract and annotate } \\
\text { at the end of page } 5 \text { in order to avoid } \\
\text { unnecessary confusion of reader. }\end{array}$ & $\begin{array}{l}\text { (Line 117-120) } \\
\text { Integrated project delivery (IPD) is one promising relational } \\
\text { contract system that provides a platform for projects. } \\
\text { Comparing to the traditional PDSs tightened by strict terms }\end{array}$ \\
\hline
\end{tabular}




\begin{tabular}{|c|c|c|}
\hline & & $\begin{array}{l}\text { and condition, since relational contract system is structured } \\
\text { by the mutual trust rather than contract clauses, it has fewer } \\
\text { changes and a tighter schedule than traditional PDSs (AIA, } \\
\text { 2007a). } \\
\text { (End of page 5. Annotation) } \\
\text { A relational contract is a contract whose effect is based upon } \\
\text { a relationship of trust between the parties to which it } \\
\text { pertains. }\end{array}$ \\
\hline $\begin{array}{l}\text { It was not clear how the author develop DV?. Need to } \\
\text { explain further on the development of DV in the } \\
\text { literature review }\end{array}$ & $\begin{array}{l}\text { As reviewer's comment, we elaborate how } \\
\text { the dependent variables are developed. }\end{array}$ & $\begin{array}{l}\text { (Line 159-161) } \\
\ldots \text { first determined, and then semi-structured interviews and } \\
\text { questionnaire surveys were carried out to determinate the } \\
\text { prerequisites for implementation of IPD that are used as } \\
\text { dependent variables in multiple regression analysis and to } \\
\text { ensure reliable data collection. Factor analysis.... } \\
\text { (Line 179-185) } \\
\text { Using their empirical experience and expertise, they } \\
\text { reviewed the different essential prerequisites potential IPD } \\
\text { factors to determine the most influential ones. They alse and } \\
\text { determined three dependent variables that are the least or } \\
\text { most critical for a successful application of IPD in the } \\
\text { Korean construction industry. These three dependent } \\
\text { variables indispensable conditions were analyzed using were } \\
\text { collected from different references (Middlebrooks, 2008; } \\
\text { Kent and Becerik-Gerber, 2010; Raisbeck, et al., 2010) were } \\
\text { discussed and finally chosen by semi-structured interviews. } \\
\text { seven factor clusters (FCs) (see Table VI). }\end{array}$ \\
\hline $\begin{array}{l}\text { Since this study is testing the relationship between IV } \\
\text { and DV, the author should include a framework and } \\
\text { hypothesis. }\end{array}$ & $\begin{array}{l}\text { As reviewer's comment, we elaborate the } \\
\text { framework and hypothesis of research } \\
\text { analysis and method. }\end{array}$ & $\begin{array}{l}\text { (Line 208-219) } \\
\text { Based on the results of factor analysis, a multiple } \\
\text { regression analysis was performed to test the relationship } \\
\text { between on the seven factor clusters (FCs; independent } \\
\text { variables) FCs and three prerequisites (dependent variables) } \\
\text { for a successful application of IPD. to analyze the } \\
\text { eontributions of individual factors to IPD introduction. The } \\
\text { results show the independent variables (FCs) showed which } \\
\text { ESFs are positively related to strecessful IPD introduction in } \\
\text { Korea that have a positive correlation with dependent }\end{array}$ \\
\hline
\end{tabular}




\begin{tabular}{|c|c|c|}
\hline & & $\begin{array}{l}\text { variables (three prerequisites for IPD) according to the beta } \\
\text { coefficient and t-test. This study hypothesizes that } \\
\text { successful FCs (independent variables) should satisfy the } \\
\text { prerequisites (dependent variables). Thus, only FCs that } \\
\text { have significant correlation with three prerequisites } \\
\text { (dependent variables) will be recognized as CSFs for IPD } \\
\text { application. Multiple regression analysis indicated } \\
\text { cerrelations between the seven FCs (independent variables) } \\
\text { and three sucessful application conditions (dependent } \\
\text { variables). } \\
\text { (Line 293-300) } \\
\text { Stepwise multiple regressions were carried out to test how } \\
\text { much correlation between the three dependent variables and } \\
\text { seven FCs as independent variables using SPSS } 22.0 \text {. In } \\
\text { accordance with the hypothesis of this study in which only } \\
\text { successful independent variables (FCs) will be recognized as } \\
\text { the SCFs for implementation of IPD in Korea, } 7 \text { FCs were } \\
\text { analyzed to see how significant correlation were with three } \\
\text { dependent variables using multiple regression analysis. } \\
\text { Since the purpose of this study is not to recognize whether a } \\
\text { certain independent variable may become the CSF but to } \\
\text { recognize what independent variables can be CSFs for IPD } \\
\text { implementation, multiple regression analysis was used to } \\
\text { find out multiple CSFs. }\end{array}$ \\
\hline $\begin{array}{l}\text { Page 7, line 193- 'Multiple regression analysis } \\
\text { indicated correlations between the seven FCs } \\
\text { (independent variables) and three successful } \\
\text { application conditions (dependent variables)'- } \\
\text { Determination on the relationship between IV and DV } \\
\text { is based on multiple regression result.Would like to } \\
\text { suggest the author to exclude the correlation result. }\end{array}$ & $\begin{array}{l}\text { As reviewer's comment, we remove the } \\
\text { " } 4.3 \text { Correlation analysis" section in order } \\
\text { to avoid confusion of reader. }\end{array}$ & $\begin{array}{l}\text { (Line 277-290) } \\
4.3 \text { Correlation analysis } \\
\text { Correlation analysis was conducted to investigate the } \\
\text { relationships between independent variables (the seven FCs) } \\
\text { and dependent variables determined from the interviews, as } \\
\text { shown in Table V. Three dependent variables were- } \\
\text { recognized as fundamental criteria when deciding whether } \\
\text { the seven analyzed FCs are critical for IPD implementation } \\
\text { in Korea. } \\
\text { Insert < Table VI. Results of correlation analysis }>\text { here } \\
\text { The correlation analysis results show that there is a }\end{array}$ \\
\hline
\end{tabular}




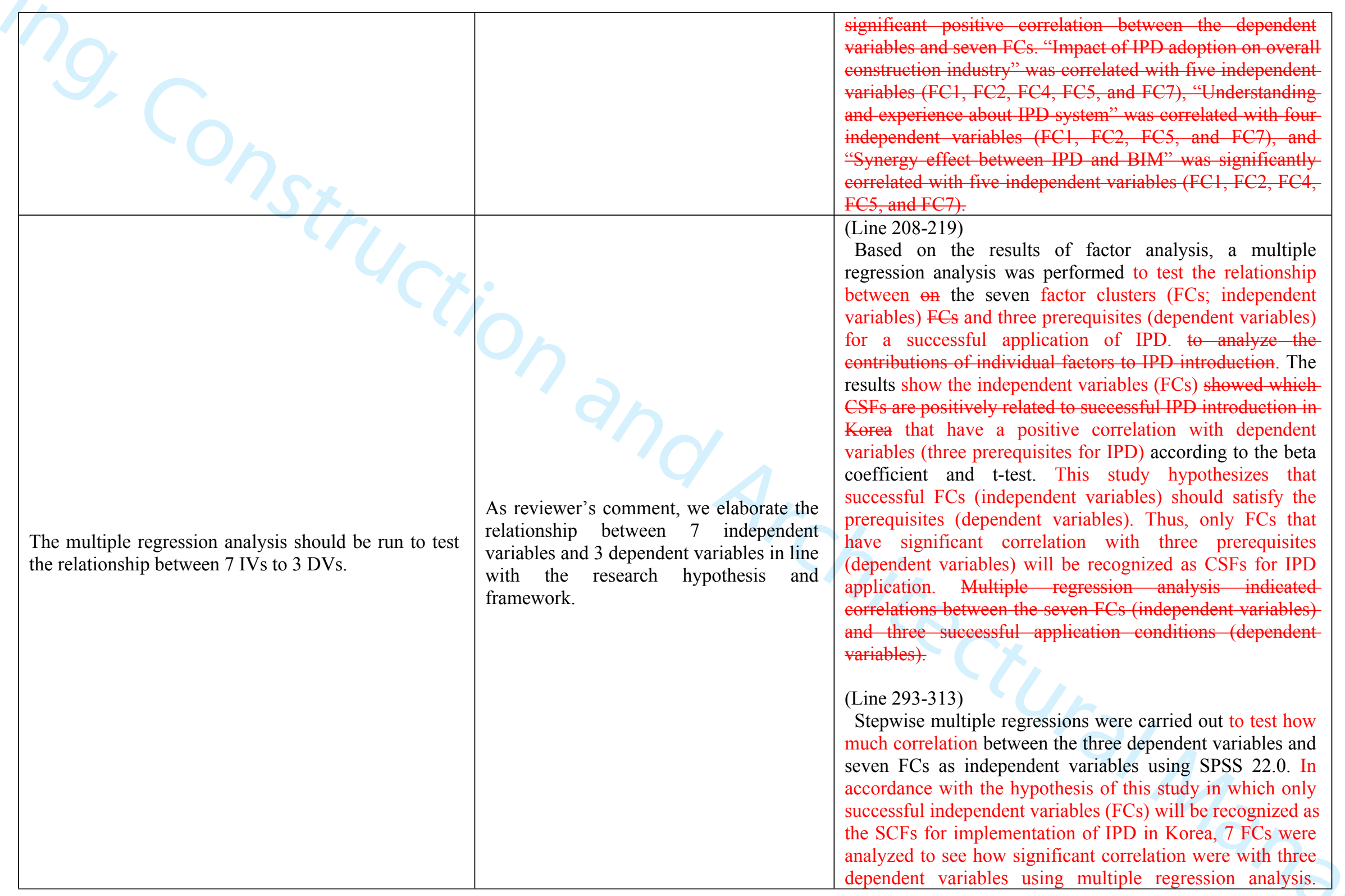




\begin{tabular}{|c|c|c|}
\hline & & $\begin{array}{l}\text { Since the purpose of this study is not to recognize whether a } \\
\text { certain independent variable may become the CSF but to } \\
\text { recognize what independent variables can be CSFs for IPD } \\
\text { implementation, multiple regression analysis was used to } \\
\text { find out multiple CSFs. Table V VII shows the standardized } \\
\text { regression coefficient ( } \beta \text { ), standard significance (p), } \\
\text { coefficient of determination (R2), adjusted R-square value } \\
\text { (Adjusted R2), and variation in the R-square value ( } \triangle \text { R2). } \\
\text { The size of the sample used in the final outcome is } 118 \text {. } \\
\text { Among the seven independent variables, only four (FCs), } \\
\text { were analyzed with a significant correlation showing the } \\
\text { differences from 0.000 at p } \leq 0.04 \text { : "Reform of the contract } \\
\text { law and adoption of appropriate IPD agreement form" } \\
\text { (CF1), "Team building and management for collaborative } \\
\text { business process" (CF2) "Early involvement and enhanced } \\
\text { role of key participants" (CF4), and "Improvement and } \\
\text { utilization of BIM for collaborative process of IPD" (CF7). } \\
\text { Insert < Table V VII. Multiple regression result > here } \\
\text { These four independent variables (CSF1, CSF2, CSF3, } \\
\text { CSF4) (CSFs) altogether explained } 60.7 \% \text { (R2=0.607) of the } \\
\text { variance of the three dependent variables (Table V VII). } \\
\text { Among the.... }\end{array}$ \\
\hline $\begin{array}{l}\text { Table VII. should be modified-there should be only one } \\
\text { model that is one result indicating relationship between } \\
\text { 7IVs and 3DVs. }\end{array}$ & $\begin{array}{l}\text { Regression analysis is a set of statistical } \\
\text { processes for modeling and analyzing } \\
\text { several variables, when the focus is on the } \\
\text { relationship between a dependent variable } \\
\text { and one or more independent variables. } \\
\text { Since this study intended to identify } \\
\text { several critical success factors (CSFs) not } \\
\text { only one, multiple regression analysis was } \\
\text { utilized to recognized multiple } \\
\text { independent variables (CSFs) for } \\
\text { successful application of IPD in Korea. }\end{array}$ & \\
\hline $\begin{array}{l}\text { Suggest data in Table III.and Table } \mathbb{V} \text { to be combined } \\
\text { in Table V. }\end{array}$ & $\begin{array}{l}\text { As reviewer's comment, we combined } \\
\text { tables. We combined Table IV and V. } \\
\text { However, Table III remains separately for }\end{array}$ & $\begin{array}{l}\text { (Line 259-263) } \\
\text { Insert }<\text { Table IV. Final statistic of principal component } \\
\text { analysis }>\text { here }\end{array}$ \\
\hline
\end{tabular}




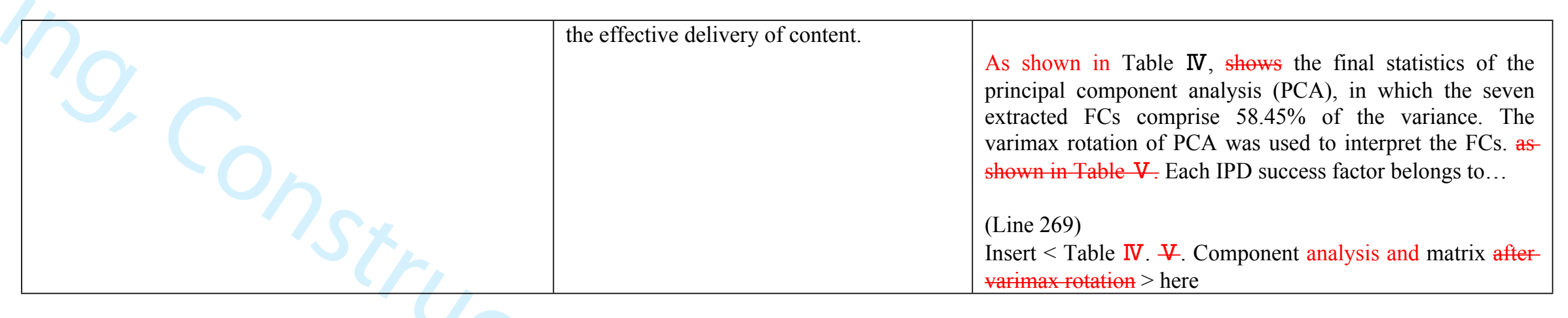

